\title{
Features
}

\section{Plastics: Modifying the Microclimate for the Production of Vegetable Crops}

\author{
William James Lamont, Jr.
}

ADDITIONAL INDEX WORDs. greenhouses, plastic mulches, polyethylene, row covers, windbreaks, high tunnels, low tunnels, season extension

SuMMARY. For centuries horticulturists have attempted to modify the environment in which vegetable crops are grown. A wide variety of techniques, such as glass cloches, hotcaps, cold frames, hotbeds, and various types of glass greenhouses, have been used to extend the production season. The discovery and development of the polyethylene polymer in the late 1930s, and its subsequent introduction in the early 1950 s in the form of plastic films, mulches, and drip-irrigation tubing and tape, revolutionized the commercial production of selected vegetable crops and gave rise to a system of production known as plasticulture. Simply defined, plasticulture is a system of growing vegetable crops where significant benefit is derived from using products derived from polyethylene (plastic) polymers. The later discovery of other polymers, such as polyvinyl chloride, polypropylene, and polyesters, and their use in microirrigation systems, pipes, fertigation equipment, filters, fittings and connectors, containers for growing transplants, picking and packaging containers, and row covers further extended the use of plastic components in this production system. The complete plasticulture system consists of plastic and non-plastic components: plastic mulches, drip-irrigation, fertigation/chemigation, soil sanitation (fumigation and solarization), windbreaks, stand establishment technology, season-extension technology, integrated pest management, cropping strategies, and postharvest handling and marketing. In the plasticulture system, plastic-covered greenhouses, plastic mulches, row covers, high tunnels, and windbreaks both permanent and annual are the major contributors to modifying the cropping environment of vegetable crops, thus enhancing crop growth, yield, and quality. In addition to modifying the soil and air temperatures, there are also the benefits of protection from the wind and in some instances rain, insects, diseases, and vertebrate pests.

$\mathrm{W}$ ittwer (1993) stated that the "initial driving forces for the use of plastics in horticulture were, first, to increase earliness and total crop productivity of high value horticultural crops; second, to take advantage of out-of-season production; and third, to use something as

Professor, Department of Horticulture, 206 Tyson Building, The Pennsylvania State University, University Park, PA 16802. effective, but much less expensive, than glass as a protective covering." Plasticulture is a management tool that enables vegetable producers to realize greater returns per unit of land by modifying the microclimate around the crop. Such a system may offer many benefits referenced in Lamont (1993):

- Earlier crop production ( 7 to 21 $\mathrm{d}$ earlier in the field)

- Higher yields per unit area (two to three times higher) produce

- Cleaner and higher quality

- More efficient use of water resources

- Reduced leaching of fertilizers, especially on lighter, sandy soils

- More efficient use of fertilizer through the utilization of fertigation technology

- Reduced soil and wind erosion

- Potential decrease in the incidence of disease

- Better management of certain insect pests

- Fewer weed problems

- Reduced soil compaction and elimination of root pruning

- Opportunity to double- or triple-crop with maximum efficiency.

Crops that have shown significant increases in earliness, yield, and/or fruit quality with the use of plasticulture include tomato (Lycopersicon esculentum), eggplant (Solanum melongena), pepper (Capsicum annuum), muskmelon (Cucumis melo), cucumber (Cucumissatious), summer squash (Cucurbitapepo), watermelon (Citrullus lanatus), and okra (Abelmoschus esculentus) (Bhella, 1978, 1986; Bhella and Kwolek, 1984; Brown et al., 1986; Paterson, 1980; Pollack et al., 1969; Schales and Sheldrake, 1966; Stephenson and Bergman, 1963). Other crops, such as sweet corn (Zea mays), snap bean (Phaseolus vulgaris), pumpkin (Cucurbita pepo), cole crops (Brassica oleracea), potato (Solanum tuberosum), and herbs (Lamont et al., 2002; Pollack et al., 1969), have shown similar responses and may lend themselves to double- or triple-cropping strategies.

\begin{tabular}{llll}
$\begin{array}{l}\text { Units } \\
\text { To convert U.S. to SI, } \\
\text { multiply by }\end{array}$ & U.S. unit & SI unit & $\begin{array}{l}\text { To convert SI to U.S., } \\
\text { multiply by }\end{array}$ \\
\hline 0.3048 & $\mathrm{ft}$ & $\mathrm{m}$ & 3.2808 \\
2.5400 & $\mathrm{inch}(\mathrm{es})$ & $\mathrm{cm}$ & 0.3937 \\
0.4536 & $\mathrm{lb}$ & $\mathrm{kg}$ & 2.2046 \\
0.0254 & $\mathrm{mil}$ & $\mathrm{mm}$ & 39.3701 \\
33.9057 & $\mathrm{oz} / \mathrm{yard}^{2}$ & $\mathrm{~g} \cdot \mathrm{m}^{-2}$ & 0.0295 \\
$\left({ }^{\circ} \mathrm{F}-32\right) \div 1.8$ & ${ }^{\circ} \mathrm{F}$ & ${ }^{\circ} \mathrm{C}$ & $\left(1.8 \times{ }^{\circ} \mathrm{C}\right)+32$
\end{tabular}




\section{Plastic-covered greenhouses}

The late Dr. E.M. Emmert, from the University of Kentucky, recognized by many as the "Father of Plasticulture" in the U.S., was a pioneer in the development of plastic-covered greenhouses for the production of vegetables. Dr. Emmert's early designs consisted of crude wooden structures covered with stretched cellophane supported by wires. Emmert's plastic houses resembled the early glass greenhouses built from glass sashes. Commercial crops of tomatoes, cucumbers, and bedding plants were grown in these structures for several years. When polyethylene became available in the early 1950s, Emmert utilized it for covering wooden frame greenhouse structures and as a mulch film for the production of muskmelons \{pictured on the front cover of a 1967 issue of HortScience $[2(1)]\}$. The first plastic greenhouse was constructed at the Kentucky Agricultural Experiment Station in 1953. This was the beginning of the use of plastic-covered greenhouses for the production of tomatoes, cucumbers, and leaf lettuce (Lactuca sativa) for the off-season markets. The new plastic-covered greenhouses were less expensive than the traditional glass greenhouses. During this period a tremendous amount of collaborative research between university scientists and industry focused on improving the quality of the plastic coverings, evaluating the use of a double layer of plastic instead of a single layer for energy conservation and improving the ventilation and heating systems. Much of this pioneering research has been published in the publications of ASHS and also in the Proceedings of the National Agricultural Plastics Association, later called the American Society for Plasticulture.

\section{Plastic mulches}

Plastic mulches have been used commercially on vegetables since the early 1960s. Much of the early research before 1960 was conducted on the impact of color (black and clear) on soil and air temperature, moisture retention, and vegetable yields (Emmert, 1957). Most plastic mulches used in the United States are made of either linear low- or high-density polyethylene and are 0.5 to $1.25 \mathrm{mil}$ thick, 48 to 60 inches wide, and on rolls 2000 to $4000 \mathrm{ft}$ long, depend- ing on the thickness of the mulch. The linear high-density polyethylene is used to reduce weight and cost and is stronger than the same thickness of low-density polyethylene. The plastic mulch is either slick (smooth) or embossed with a diamond-shaped pattern. This pattern helps reduce expansion and contraction, which results in the loosening of the mulch from the raised bed. The raised bed is generally 4 to 6 inches high and 30 inches wide and has a slope of 1.25 inches from the center to the edge (Lamont, 1993). Plastic mulch is applied to the raised bed in either single or multiple operations. Soil under a raised bed covered with plastic mulch will warm up more quickly in the spring and also will shed excess water off the bed into row middles, thus keeping the crop plants drier and preventing deterioration in quality of the product.

Plastic mulches directly impact the microclimate around the plant by modifying the radiation budget (absorbitivity vs. reflectivity) of the surface and decreasing the soil water loss (Liakatas et al., 1986; Tanner, 1974). The color of plastic mulch largely determines its energy-radiating behavior and its influence on the microclimate around a vegetable plant. Color affects the surface temperature of the mulch and the underlying soil temperature. Ham and Kluitenberg (1994) found that the degree of contact between the mulch and soil, often quantified as a thermal contact resistance, greatly affects the performance of a mulch. A rough, cloddy soil surface creates an air space between the plastic mulch and the soil surface and results in less effective warming of the soil than would be expected from that particular mulch on a smooth soil surface (Ham and Kluitenberg, 1994).

The temperature of the soil measured under plastic mulch depends on the thermal properties (reflectivity, absorbitivity, or transmittancy) of a particular material in relation to incoming solar radiation (Schales and Sheldrake, 1963). Black plastic mulch, the predominant color used in vegetable production, is an opaque blackbody absorber and radiator. Black mulch absorbs most ultraviolet, visible, and infrared wavelengths of incoming solar radiation and reradiates absorbed energy in the form of thermal radiation or long-wavelength infrared radiation. Much of the solar energy absorbed by a black plastic mulch is lost to the atmosphere through radiation and forced convection. The efficiency with which black mulch increases soil temperature can be improved by optimizing conditions for transferring heat from the mulch to the soil. Because thermal conductivity of the soil is high relative to that of air, much of the energy absorbed by black plastic can be transferred to the soil by conduction if contact is good between the plastic mulch and the soil surface. Soil temperatures under black plastic mulch during the daytime are generally $5{ }^{\circ} \mathrm{F}$ higher at a 2 -inch depth and $3{ }^{\circ} \mathrm{F}$ higher at a 4 -inch depth compared to those of bare soil (Ham et al., 1993).

In contrast, clear plastic mulch absorbs little solar radiation but transmits $85 \%$ to $95 \%$, with relative transmission depending on the thickness and degree of opacity of the polyethylene. The under surface of clear plastic mulch usually is covered with condensed water droplets. This water is transparent to incoming shortwave radiation but is opaque to outgoing longwave infrared radiation, so much of the heat lost to the atmosphere from a bare soil by infrared radiation is retained by clear plastic mulch. Thus, daytime soil temperatures under clear plastic mulch are generally 8 to $14^{\circ} \mathrm{F}$ higher at a 2 -inch depth and 6 to $9^{\circ} \mathrm{F}$ higher at a 4-inch depth compared to those of bare soil (Ham et al., 1993). Clear plastic mulches generally are used in the cooler regions of the United States, such as the New England states. Using clear plastic mulch requires the use of a herbicide, soil fumigant, or solarization to control weeds.

The use of white, coextruded white-on-black or metallized silver mulches results in a slight decrease in soil temperature, $-2{ }^{\circ} \mathrm{F}$ at a 1 -inch depth or $-0.7^{\circ} \mathrm{F}$ at a 4 -inch depth compared to bare soil, because they reflect back into the plant canopy most of the incoming solar radiation (Ham et al., 1993). These mulches are used to establish a crop when soil temperatures are high and any reduction in soil temperatures is beneficial. Depending on the degree of opacity of white mulch, it may require the use of a fumigant or herbicide because of the potential weed growth.

Another family of mulches includes the wave-length-selective or photoselective mulches, which selectively transmit radiation in some 
regions of the electromagnetic spectrum but not in the photosynthetic wavelength (Loy et al., 1989). These mulches absorb photosynthetically active radiation $(P A R)$ and transmit solar infrared radiation, providing a compromise between black and clear mulches. The infrared-transmitting (IRT) mulches afford the weed control properties of black mulch but are intermediate between black and clear mulch in terms of increasing soil temperature. Colors of IRT mulches include bluegreen or brown and will warm up the soil like clear mulch but without the accompanying weed problem.

Research continues on the use of red, blue, yellow, gray, and orange, which have distinct optical characteristics and thus reflect different radiation patterns into the canopy of a crop, thereby affecting plant growth and development (Decoteau et al., 1989; Ngouajio et al., 2003; Orzolek and Murphy, 1993). In a study by Loy et al. (1998), differences in reflectivity among a red, black and red-on-black mulch were minimal at 16 inches above the mulch surface and on the shaded side of the row. They speculate that for red mulch reflectivity to have a more sustained and more consistent effect on biomass accumulation and yield in tomato the rows may need to be oriented in a north-south direction. This light reflectivity affects not only crop growth but also insect response to the plants grown on the mulch. Examples are yellow, red, and blue mulches, which increased green peach aphid (Myzus persicae) populations (Orzolek and Murphy, 1993), especially the yellow color, which attracted increased numbers of striped cucumber beetles $(D i$ abrotica vittata) and spotted cucumber beetles (Diabrotica undecimpunctata). Yellow sticky traps are routinely used in greenhouses to monitor insects. Researchers have shown that mulches with a printed silver surface color or metallized silver surface repel certain aphid species and reduce or delay the incidence of aphid-borne viruses in summer squash (Lamont et al., 1990). Similar to white color mulch, the degree of opacity of gray mulch may require a herbicide or fumigant to be used to prevent weed growth.

In response to the disposal problem with non-degradable mulch films, photodegradable plastic mulches were developed (Ennis, 1987). Although photodegradable plastic looks very much like other plastic mulches installed, it breaks down by exposure to ultraviolet sunlight. The actual rate of breakdown depends on several factors, including temperature, the proportion of the plastic shaded by the crop, and the amount of sunlight received during the growing season. When using photodegradable plastic mulch, it is important to realize that decomposition of the buried edges (commonly referred to as the tuck) is initiated by lifting them out of the soil and exposing them to sunlight. Research continues on some newer biodegradable mulches (Gioffre, 2003; Versari and Guerrini, 2003 ) as one answer to the disposal problem associated with the use of non-degradable plastics.

\section{Windbreaks}

The use of windbreaks, permanent (trees) and annual (small grain), or the newer plastic webbed materials, is an important part of the entire plasticulture system, but is often overlooked. Windbreaks, consisting of strips of winter wheat (Triticum aestivum), rye (Secale cereale), or barley (Hordeum vulgare), should be established to protect young vegetable seedlings from prevailing winds. The use of permanent (trees and shrubs) and annual windbreaks (small grains or plastic) can modify wind profiles and influence temperatures and other microclimate features (Hodges et al., 1994). Also, windbreaks serve as habitat for beneficial and pest insects (Dix and Leatherman, 1988).

For maximum effectiveness of an annual small grain windbreak, the grain strips should be planted in the fall. Each grain strip should be the width of a small-grain drill, 10 to $12 \mathrm{ft}$, with strips far enough apart to accommodate five or six mulched beds on 5 - to 6 - $\mathrm{ft}$ centers. Topdressing the strips in the spring helps to ensure a dense stand of grain that will then provide the maximum protection from the cold spring winds.

Another option for annual small grain windbreak is to plant the entire field to a solid grain cover crop in the fall. In the spring, the area where the plastic mulch and drip irrigation beds are to be made will be tilled, leaving strips of small grain between five to six plastic-covered raised beds. It is important to till the crop area early enough in spring so that cover crop debris will not interfere with applica- tion of the plastic mulch and drip irrigation. Once wind protection is no longer required, the grain strips are mowed and used as drive rows for spraying for insect and disease control and for harvesting.

\section{Season-extending technology}

ROW COVERS OR LOW TUNNELS. Early production of vegetables is possible by creating a mini-greenhouse effect. The first rowcovers used for high-value field-grown vegetable crops were not plastic but were a parchment paper used for covering early spring plantings of celery (Apium graveolens) for protection against wind, cold rains, and frost in the Grand Rapids and Kalamazoo areas of Michigan. This use preceded the use of plastic by more than 50 years (Wittwer and Lucas, 1956).

Again Dr. Emmert (1957) was a pioneer in the research on rowcovers. Later the research of Shadbolt and McCoy (1960) established the benefits of using rowcovers in place of individual hot tents or caps. Hall and Besemer (1972) commercialized the use of solid polyethylene sheeting that needed support and required venting during the day for the production of tomatoes, cucumbers, and peppers in San Diego County, Calif.

To eliminate the need for manual venting of solid polyethylene row covers, which was very labor intensive, a variety of new materials was developed to cover single or multiple rows: slits or a pattern of holes in polyethylene covers that required supporting wire hoops; a floating nonwoven sheet; a white point-bonded, polypropylene material; a spunbonded polyester fabric; $1.25 \mathrm{oz} /$ yard $^{2}$ polypropylene; a polyethylene sheet with tiny pores (Wells and Loy, 1985a, 1985b). Another use of rowcovers is as physical barriers that exclude insect pests and protect the crop in the early stages of growth (Natwick and Durazo, 1985). The use of rowcovers for protection of early warm-season crops is widespread throughout the U.S (Wells, 1996).

High tunnels. High tunnels, although resembling a traditional plasticcovered greenhouse discussed earlier, are a completely different technology. They are considered a non-permanent (removable) structure with no electrical service or automated ventilation or heating system that is covered by a single layer of plastic compared to 
two layers used in a traditional plasticcovered greenhouse. Water service is required for irrigation of the crop. They may be minimally heated to protect against unexpected drops in temperature. They are primarily used to extend the spring and fall growing seasons (Wells, 1991).

In addition to temperature control, there are also the benefits of wind and rain protection, soil warming, and in some instances control of insects, diseases, and predators such as varmints and birds. Overall, high tunnel growing systems should be considered protected growing systems that enhance earliness and higher yields, improve quality, and reduce the use of pesticides in some cases.

Research on the use of high tunnels for extending the growing season and, in some instances, depending on location, producing 12 months a year has increased dramatically in recent years (Jayaprakash et al., 2003; Jett and Read, 2003; Lamont et al., 2003a). A wide variety of vegetable crops has been grown in high tunnels (Lamont et al., 2003b). A number of other environmental modifying technologies using plastics can be used in the high tunnels (plastic mulches, rowcovers or low tunnels, and thermal blankets) to further modify the growing environment and extend the production season (Lamont et al., 2003b). High tunnels have been in widespread use in many parts of the world, especially in Asia and the countries of Spain and Italy, for years but are a recent introduction to the U.S. (Wells, 1991)

\section{Disposal of the used plastics from the plasticulture system}

This is the one question that is always asked by people who are interested in or are using plastics to modify the cropping environment: "What do I do with the plastics when I am done using them?" It is certainly a problem that is a concern not just in the U.S. but also worldwide in its scope. There have been and continue to be many attempts at solving this problem, such as the development and use of photodegradable or biodegradable materials (just disappear), using the plastics several times (delaying the problem), reducing the weight of films (less material to deal with), recycling (made into other products), and incineration (Hemphill, 1993). The mulch films and drip irrigation tapes are by far the hardest to deal with since after a season in the field, these materials have a lot of plant debris, dirt, and moisture associated with them, which makes it difficult to recycle them. One option is to incinerate them to recover the very substantial fuel value ( $1 \mathrm{~kb}$ of plastics has as much potential energy as an equivalent amount of fuel oil). These used plastics have been burned in waste-to-energy plants, but one problem is that plastics burn hotter than the surrounding waste; thus, "hot spots" are created in the waste stream. A team of researchers at The Pennsylvania State University, University Park, are testing "Plastofuel," a "fuel nugget"made from used agricultural plastics such as plastic mulches, drip irrigation tape and tubing, row covers, pots, trays, flats, silage bags, and hay wraps. The Plastofuel can be burned as a supplement to coal or other waste products, or by itself in a burner unit developed in South Korea, which is to be tested in the near future to heat a wide variety of structures (Garthe et al., 2003). In addition to the emission testing to be conducted on the burner unit, research needs to be done on the proper collection, preparation, and transportation of the plastics from the crop production site to the point where it is processed further (Plastofuel) and then to the point of incineration.

\section{Conclusions}

The development and use of plastic polymers revolutionized not only the production of vegetable crops as noted in the following review articles (Hochmuth and Hochmuth, 1993; Lamont, 1993; Wittwer, 1993), but also the production of horticultural crops worldwide (Larson, 1993). It certainly has had a great impact on the production of vegetable crops, not only in the U.S., but worldwide. The use of plastics has been shown to modify the crop production environment as well as provide a host of other beneficial uses in vegetable crop production, from plant growing containers to packaging of the final product. As we look to the future, one of the greatest challenges not only in the use of plastics for the production of vegetables, but in society at large, is dealing with all the plastic waste that is generated in an environmentally sound and safe way. This is really the final piece of the plasticulture system that needs to be put in place so that the circle, from manufacturing of a plastic product, through its use and then disposal is complete. This is the challenge for the future.

\section{Literature cited}

Bhella, H.S. 1978. Watermelon growth, yield and nutrition as influenced by plastic mulch and trickle irrigation. Proc. 19th Natl. Agr. Plastics Congr., p. 295-301.

Bhella, H.S. 1986. Effect of plastic mulch and trickle irrigation on tomato growth, yield and nutrition. Proc. 19th Natl. Agr. Plastics Congr., p. 80-86.

Bhella, H.S. and W.F. Kwokek. 1984. The effects of trickle irrigation and plastic mulch on zucchini. HortScience 19:410-411.

Brown, J.E., G.A. Lewis, and H.M. Bryce. 1986. Influence of black plastic mulch and row covers on the growth and performance of okra intercropped with turnip greens. Proc. 19th Natl. Agr. Plastics Congr., p. 148-157.

Decoteau, D.R., M.J. Kasperbauer, and P.G. Hunt. 1989. Mulch surface color affects yield of fresh-market tomatoes. J. Amer. Soc. Hort. Sci. 114:216-219.

Dix, M.E. and D. Leatherman. 1988. Insect management in windbreaks, p. 501-502. In: J.R. Brandle, D.L. Hintz, and J.W. Sturrock (eds.). Windbreak technology: Proceedings of an international symposium on windbreak technology. Elsevier, New York.

Emmert, E.M. 1957. Black polyethylene for mulching vegetables. Proc. Amer. Soc. Hort. Sci. 69:464-469.

Ennis, R.S. 1987. Plastigone®: A new, time-controlled photodegradable plastic mulch film. Proc. 20th Natl. Agr. Plastics Congr., p. 83-90.

Garthe, J.W., B.G. Miller, R.S. Wasco, W.J. Lamont, and M.D. Orzolek. 2003. Used agricultural plastic as a coal fuel supplement. Proc. 31st Natl. Agr. Plastics Congr., p. 53-57.

Gioffre, T. 2003. What's new in biodegradable plastics. Proc. 31st Natl. Agr. Plastics Congr., p. 44.

Hall, B.J. and S.T. Besemer. 1972. Agricultural plastics in California. HortScience 7:373-378.

Ham, J.M., G.J. Kluitenberg, and W.J. Lamont. 1993. Optical properties of plastic mulches affect the field temperature regime. J. Amer. Soc. Hort. Sci. 228(2):188-193.

Ham, J.M. and G.J. Kluitenberg. 1994. Modeling the effect of mulch optical properties and mulch-soil contact resistance on soil heating under plastic mulch culture. Agr. For. Meteorol. 71:403-424. 
Hemphill, D.D. 1993. Agricultural plastics as solid waste: What are the options for disposal? HortTechnology 3(1):70-73.

Hochmuth, R.C. and G.J. Hochmuth. 1993. Use of plastics in greenhouse vegetable production in the United States. HortTechnology 3(1):20-27.

Hodges, L., M.E. Dix, J. Brandle, R. Wright, and M. Harrell. 1994. Effects of shelterbelts on insect pests in muskmelon. Proc. Nebraska Fruit Veg. Growers Conf., p. 19-18.

Jayaprakash, A.K., L. Hodges, K. Eskridge, and D. Travicek. 2003. Predicting temperatures in high tunnels using a mathematical model. Proc. 31st Natl. Agr. Plastics Congr., p. 78-82.

Jett, L. and A. Read. 2003. Developing a successful high tunnel tomato cropping system in the Great Plains. Proc. 31 st Natl. Agr. Plastics Congr., p. 59-62.

Lamont, W.J. 1993. Plastic mulches for production of vegetable crops. HortTechnology 3(1):35-39.

Lamont, W.J. 2002. Production of drip irrigated potatoes as affected by plastic mulches and row covers. J. Veg. Crop Production 8(2):39-47.

Lamont, W.J., M.D. Orzolek, E. Jay Holcomb, K. Demchak, E. Burkhart, L. White, and B. Dye. 2003b. Production system for horticultural crops grown in the Penn State high tunnel. HortTechnology 13(2):358-362.

Lamont, W.J., M.D. Orzolek, L. White, and B. Dye. 2003a. Production System for Vegetable Crops Grown in Penn State High Tunnels. Proc. 31 st Natl. Agr. Plastics Congr., p. 87.

Lamont, W.J., K.A. Sorensen, and C.W. Averre. 1990. Painting aluminum strips on black plastic mulch reduces mosaic symptoms on summer squash. HortScience 25:1305.
Larson, R.A.1993. Impact of plastics in the floriculture industry. HortTechnology 3(1):28-34.

Liakatas, A., J.A. Clark, and J.L. Monteith. 1986. Measurements of the heat balance under plastic mulches. Part I. Radiation balance and soil heat flux. Agr. For. Meteorol. 36:227-239.

Loy, B., J. Lindstrom, S. Gordon, D. Rudd, and O. Wells. 1989. Theory and development of wavelength selective mulches. Proc. 21st Natl. Agr. Plastics Congr., p. 193-197.

Loy, B., O.S. Wells, N. Karakoudas, and K. Milbert. 1998. Comparative effects of red and black polyethylene mulch on growth, assimilate partitioning, and yield in trellised tomato. Proc. 27th Natl. Agr. Plastics Congr., p. 188-197.

Natwick, E.T. and A. Durazo, III. 1985. Polyester covers protect vegetables from whiteflies and virus disease. Calif. Agr. $39(7+8): 21-22$.

Ngouajio, M., R. Goldy, S. Snapp, and B. Zandstra. 2003. Effect of colored polyethylene mulches on fresh market tomato growth and yield. Proc. 31st Natl. Agr. Plastics Congr., p. 100-105.

Orzolek, M. D. and J. H. Murphy. 1993. The effect of colored polyethylene mulch on the yield of squash and pepper. Proc. 24th Natl. Agr. Plastics Congr., p. 157-161.

Paterson, J.W. 1980. Fertilizing mulched and unmulched cucumbers. Proc. 15th Natl. Agr. Plastics Congr., p. 97-99.

Pollack, G.L., N.J. Smith, and J.C. Cialone. 1969. Summary of crop response to various agricultural film mulches. Proc. 9th Natl. Agr. Plastics Conf., p. 17-25.

Schales, F.D. and R. Sheldrake. 1963. Mulch effects on soil conditions and tomato plant response. Proc. 4th Natl. Agr. Plastic Conf., p. 78-90.
Schales, F.D. and R. Sheldrake. 1966. Mulch effects on soil conditions and muskmelon response. Proc. Amer. Soc. Hort. Sci. 88:425-430.

Shadbolt, C.A. and O.D. McCoy. 1960. Temperature and plant responses to paper and plastic protectors on cantaloupes. Hilgardia 30:247-266.

Stephenson, K.Q. and E.L. Bergman. 1963. Some mechanical and cultural developments on the Penn State transplanter and mulcher. Proc. 4th Natl. Agr. Plastics Conf., p. 58-64

Tanner, C.B. 1974. Microclimate modification: Basic concepts. HortScience 9:555-560.

Versari, M. and S. Guerrini. 2003. Use of Mater-Bi biodegradable mulch film in Europe. Proc. 3 lst Natl. Agr. Plastics Congr., p. 43.

Wells, O.S. 1991. High tunnels shelter early crops. Amer. Veg. Grower 39(2):44, 46-47.

Wells, O.S. and J.B. Loy. 1985a. Rowcovers: A changing landscape. HortScience 20(5):800.

Wells, O.S. and J.B. Loy. 1985b. Intensive vegetable production with rowcovers. HortScience 20:822-826.

Wells, O.S. 1996. Rowcover and high tunnel growing systems in the United States. HortTechnology 6(3):172-176.

Wittwer, S.H. 1993. World-wide use of plastics in horticultural production. HortTechnology 3(1):6-19.

Wittwer, S.H. and R.E. Lucas. 1956. Celery production in Michigan. Michigan Agr. Ext. Bul. 339. 